\title{
Five Dimensions on Xi Jinping's New Age of Socialism with Chinese Characteristics
}

\author{
Jiayue Quan ${ }^{1}$ \\ ${ }^{1}$ College of Marxism, Northwestern Polytechnical University, Xi'an, China \\ Correspondence: Jiayue Quan, College of Marxism, Northwestern Polytechnical University, Xi'an, China. Tel: \\ 153-199-38761. E-mail: quanjiayue710062@126.com
}

Received: September 21, $2018 \quad$ Accepted: October 17, 2018 Online Published: October 30, 2018
$\begin{aligned} & \text { doi:10.5539/par.v7n2p58 } \\ & \text { URL: http://dx.doi.org/10.5539/par.v7n2p58 }\end{aligned}$

The research is financed by (Sponsoring information) social science major fund project in 2017 in Shaanxi province (project number: 2017 ZD02); the ministry of education of youth fund project in 2016 (project number: 2016 YGC710022).

\begin{abstract}
Xi Jinping's New Age of Socialism With Chinese Characteristics systematically answers this basic question: "In the new era what kind of upholding and developing socialism with Chinese characteristics, how to adhere to and develop socialism with Chinese characteristics". It fully reflects the unity of The Times and people's wishes; Reflects the unity of theory innovation and practice innovation; Embodies the stick to comprehensively deepen reform and comprehensively promote the political determination and confidence of the construction of the Communist Party of China. It is guide action that leads the Chinese people of all ethnic groups to obtain a new great victory with an unyielding and overcome difficult under new historical conditions.

Xi Jinping's New Age of Socialism With Chinese Characteristics highlight four characteristics: The theory of character of inheritance and innovation, Centering on people's value concept, rock-solid political concentration, the essence of realistic and practical, the concept of Community of human destiny.
\end{abstract}

\section{Keywords:}

Xi Jinping's New Age of Socialism with Chinese Characteristics; Five Dimensions

\section{Introduction}

Xi Jinping's New Age of Socialism with Chinese Characteristics, highlights the theme of upholding and developing socialism with Chinese characteristics, in promoting the modernization of national management system and management ability as the main line, highlights the "innovation, coordination, green, open, sharing" five development concept, as the General layout "Five One" and "Four Comprehensive" strategy for basic management strategy, and emphasis to promote building community of human destiny.

\section{View}

Xi Jinxing's New Age of Socialism with Chinese Characteristics fully reflects the unified requirements of the era and the Chinese people 's wishes, and reflects the unity of theory innovation and practice innovation. And it is the guide of the Chinese people to achieve goals under the new historical conditions.

\subsection{Xi Jinping's New Age of Socialism With Chinese Characteristics is the Theory of the Inheritance, Innovation Character}

Xi Jinxing's New Age of Socialism with Chinese Characteristics is the newest theoretical results Sinicization of Marxism. It is the combination product between Marxism and the China's actual and age characteristics. It is traced the unity of scientific system With Marxism-Leninism, MAO Zedong thought, Deng Xiaoping theory, "Three Represents" Important Thought and the Scientific Outlook on Development in line. They have a common world outlook and methodology: the dialectical materialism and historical materialism, common value targets: ruling for the people, and have a common character: the theory of advancing with The Times. Maintaining and developing the Marxism party's theoretical character of keeping pace with The Times is the basic characteristics of Xi jinxing's New Age of Socialism With Chinese Characteristics. 
Xi Jinxing's New Age of Socialism with Chinese Characteristics adheres to the problem oriented, development in insisting, innovation in the inheritance. How to stick to and develop socialism with Chinese characteristics, firmly road self-confident, theory system of self-confidence, system of self-confidence, cultural self-confidence? How to comprehensively deepen reform and opening up and stimulate the development motivation and creativity of the whole society? How to promote the sustainable and healthy economic and social development? How to adhere to the socialist political development road with Chinese characteristics? How to insist on to the road of peace, development and cooperation, win-win, promote to build human destiny community, to strengthen the building of the communist party of China itself, to improve the level of comprehensive governing party? To solve above problems, it puts forward a series of practical and effective new assertion, new goals, new requirements, to further enrich and develop the system of theories of socialism with Chinese characteristics.

Xi Jinxing's New Age of Socialism With Chinese Characteristics is practical experience and the crystallization of collective wisdom of the Chinese people and the Communist Party of China. And it is the guide of the Communist Party of China and the national people's struggle. Knowing this thought has to understand socialism with Chinese characteristics into a new era of new judgment, to understand the new features of the Chinese socialist primary contradiction change and understand Chinese two-step all-round construction of the new target of modern socialist country.

\subsection{Xi Jinping's New Age of Socialism with Chinese Characteristics is Centering on People's Value Concept}

The spirit is the national responsibility, responsibility to the people, to the party's own responsibility. Xi Jinping's New Age of Socialism With Chinese Characteristics is the unity of the truth, values and history. Adhere to the "people centered", the ruling for the people has always been the value orientation of the thought. Xi Jinping stressed in the report of the 19th National Congress of the Communist Party of China: "don't forget the beginner's mind, keeping the mission in mind "; "the Beginner's mind and mission of the Communist Party of China, is seeking happiness for the people of China"; "Always putting people's yearning for a more beautiful and better life as the goal"; "Social principal contradictions of China's new era has been into the contradiction between people's increasing needs of the good life and the unbalance and inadequate development ", And he emphasized "to solve the serious problem that the people reflected", "the people against what, hate what; we will resolutely prevent and correct that"; "to base on line of the people and reflect the rights and interests of the people"; "must reflect the people's will to stimulate the creativity of the people "; "to continuously promote man's all-round development".

When it comes to reform, Xi Jinping stressed: "comprehensively deepen reform must be to promote social fairness and justice, to improve people's well being as the starting point and the foothold, and stressed "to the satisfaction of the masses as the inspection standard of reform".

At the same time, Xi Jinping Stressed to put the idea of adhering to people's main body status, insisting on quickens, ruling for the people, to carry out the implementation to the concrete practice of implementing the Strategy of rejuvenating rural, precision out of poverty, ensuring and improving people's livelihood and perfect the system of people's self-determination system, developing socialist democracy, comprehensively deepen reform deepening, comprehensive governing party, the rule of law, building a well-off society in an all-round way of concrete practice.

\subsection{Xi Jinping's New Age of Socialism with Chinese Characteristics is Reflecting a Rock-Solid Political Concentration}

Political concentration was ruling out all kinds of political ideological interference, eliminating all kinds of confusion, adhering to the correct position, to keep in the right direction. Xi Jinping's New Age of Socialism With Chinese Characteristics reflects a firm scientific belief and overtly political positions. Socialism with Chinese characteristics is the all theme of the Communist Party of China since China's reform in theory and practice, and is the ultimate achievement which was be obtained by the Communist Party of China and the Chinese people that struggled and paid a heavy price.

Xi Jinping stressed in the report of the 19th National Congress of the Communist Party of China: "the whole party do not forget the beginner's mind, keep the mission in mind, holding the great banner of socialism with Chinese characteristics"; "the party will be more consciously adhere to the leadership of the party and the socialist system in our country"; "don't shake the Chinese characteristic socialism common ideal faith consistently"; "don't shake the goal of people's yearning for a better life".

First, the political concentration is from faith, and is the result of political self-confidence. Xi Jinping stressed in the 19th National Congress of the Communist Party of China: "The road we walk is socialism with Chinese 
characteristics. It has the extremely broad age stage, a very profound historical background, and a very powerful forward concentration." The Communist Party of China has to enhance more consciously confidence of this road, the confidence of theory, the confidence of system and cultural confidence. Neither go closed rigid path, nor go to the astray which change the direction of the original road to maintain political concentration, to adhere to the pragmatic development, and always adhere to and develop socialism with Chinese characteristics."

Second, the political concentration is derived from the theoretical awake. Xi Jinping stressed: "not exactly the same in the world political system model, the political system cannot be separated from specific social and political conditions and historical and cultural traditions to abstract judgment. We cannot follow a so-called authority pattern, and copy foreign political system model regardless of the actual." In addition, he stressed that comprehensive governing party always on the road. And to promote the further development of comprehensive governing party, it puts the party's political construction in the first place, ideological construction and the system to a higher power, Strengthening inner-party supervision, developing positive and healthy inner-party political culture, to purify the party and political ecology comprehensively, punishing corruption Severely, always maintaining close contact between the party and the people.

Third, political concentration emphasizes on self-cultivation and inner consciousness. The communists must strengthen the party spirit exercise, strict political discipline and political rules, to improve political consciousness and political ability, forever communist's political nature.

Fourth, the requirement to strengthen the construction of the party's political. The party's political construction must be put in the first place. The party should firmly implement the party's political line, strictly abide by the political discipline and rules, in politics, the political orientation, political principle, political road associates the central keep highly consistent.

Profoundly grasp this idea, it is important to pay special attention to the learning throughout the vision and political confidence, commanding the whole situation theory, strategic foresight, always maintaining a rock-solid political concentration of the communist party of China.

\subsection{Xi Jinping's New Age of Socialism with Chinese Characteristics is Fully Embodying the Essence of Practical}

Xi Jinping's New Age of Socialism With Chinese Characteristics insists on emancipating the mind, seeking truth from facts and keeping pace with The Times, constantly enriching and expanding the connotation of the socialist theoretical system with Chinese characteristics. Practical and pragmatic are the essence of Marxism, and are the fine tradition of the communist party of China. Also it is an important strength of making people together and is the inevitable requirement of the reform of construction development. "Truth" is the principal contradiction of the precision of social development.

Xi Jinping stressed: "social principal contradictions of our country has been converted Contradiction between people's increasing needs for a better and more beautiful life and unbalanced inadequate development of the contradiction ". It's a new assessments and response of the Communist Party of China in the new era of China to the main problems facing contradictions. This shows that China now prominent problems are the imbalance and inadequate development. "Truth" is also reflected in the primary stage of socialism in the largest national conditions. China's basic national condition, which is still in and has long been at the primary stage of socialism's basic national conditions, does not change. China is the world's largest developing country's international status has not changed.

"Truth" is reflected in the specific measures. Such as Xi Jinping stressed "to deepen the practice of the rule of law"; establishing the central leading group for the rule of law in an all-round way, strengthening the unified leadership of the China's law construction, Promoting scientific legislation, democratic legislation and legislation in accordance with the law, to digest for development, to ensure good governance.

Xi Jinping stressed Socialism is not shouted out, but actually dry out. Xi jinping said in the 19th National Congress of the Communist Party of China: "we must stick to emancipate the mind; seek truth from facts and keep pace with The Times; adhere to the dialectical materialism and historical materialism; closely combine with the conditions and practical requirements of the new era, deepen to the ruling communist party rule in a whole new field of vision ".

Xi Jinping's New Age of Socialism With Chinese Characteristics, which adhere to the practical and pragmatic, all starting from the reality and the basic national conditions, organically unify the theory and practice, the methods and measures, knowing and doing, motive and effect of organic unity. It respects the objective laws, telling the truth, seeking practical results. 


\subsection{Xi Jinping's New Age of Socialism with Chinese Characteristics is highlighting the Concept of Community of Human Destiny}

What is a community of human destiny? Xi Jinping stressed:" build a community of human destiny, construction of lasting peace and universal security, common prosperity, open inclusive, clean beautiful world."

Why should advocate building human destiny community? In the nineteenth congress of the communist party of China, Xi Jinping pointed out that today's world is at a big development, a big change, and a big adjustment period, but peace and development remain the themes of times. Although the global governance system and the transformation of the international order is accelerating, interconnected and interdependent world also in deepening, but the International power more balanced, and peace and the development trend is irreversible. At the same time, facing the world instability and uncertainty are very outstanding; global growth momentum is insufficient; the gap between rich and poor is serious; terrorism, network security problem, infectious disease threats such as spread, the mankind is faced with many common challenges today. It is global reality basis to advocate the community of human destiny. Global problems require human face and deal with together; no country can cope with challenges of alone.

How to build a community of human destiny? In the nineteenth congress of the communist party of China, Xi Jinping pointed out that countries need to mutual respect, equal consultation and resolutely abandon cold war mentality and power politics; To adhere to dialogue to solve disputes, resolve differences in consultation; Come together, and to promote trade and investment liberalization and facilitation; To respect the diversity of world civilization, and protect the earth to the survival of humans. Build community of human destiny, key in action. We must stick to the dialogue and consultation and build a lasting peace in the world; Adhere to the co-construction and sharing, build a safer world; Adhere to the win-win cooperation, build a common prosperity of the world; Insist on communication, build an open inclusive world; Adhere to the green, low carbon, construction of a clean and beautiful world.

Xi's ideas of community of human destiny conforming the new changes of economic globalization, Concerning about the progress of human society development future, becomes common values to change the global governance system, to build a new type of international relations and international new order. "Building human destiny community" concept to be formally written to the UN resolution, suggests that the concept has been widely recognized international society. It is the creative transformation of Chinese excellent traditional culture and innovative development. It is the inheritance and innovation of Marxism-Leninism, and is scientific summary of foreign successful experience of the People's Republic of China and the theory of ascension. It provides a China and Chinese wisdom for global governance system to build the global change new order of justice.

\section{Conclusion}

From the Angle of the development history of Marxism, Xi Jinping's New Age of Socialism With Chinese Characteristics has opened up a new realm of Sinicization of Marxism. From the Angle of the history of human civilization and progress, it has contributed to the Chinese wisdom for solving the common problem of the human facing, and provides the solutions in China. From the Angle of the development of the China, Xi Jinping's New Age of Socialism with Chinese Characteristics is the guide action for realizing the great development of the Chinese nation.

\section{References}

Big important literature compilation of (in) since the eighteenth. (2017). Central literature publishing house, Beijing.

Chen, Y., \& Pu, P. (2017). Building a community of human destiny. China Renmin University Press, Beijing.

Thirty speak of Xi Jinping's New Age of Socialism with Chinese Characteristics. (2018). Learning publishing house, Beijing.

Xi, J. P. (2017a). Xi Jinping talk about governing (Vol. 2). Foreign languages publishing house, Beijing.

Xi, J. P. (2017b). Redefining a well-off society in an all-round way and seize the new era of the great victory of socialism with Chinese characteristics. People's publishing house, Beijing. 


\section{Copyrights}

Copyright for this article is retained by the author(s), with first publication rights granted to the journal.

This is an open-access article distributed under the terms and conditions of the Creative Commons Attribution license (http://creativecommons.org/licenses/by/4.0/). 